Rupantaran : A Multidisciplinary Journal

Vol. III : 17-23, March, 2020

ISSN : 2091-0061

Research Management Cell (RMC)

Dhankuta Multiple Campus, Dhankuta

Tribhuvan University, Nepal

\title{
Utilization of Remittance for Rural People's Needs: Study of Chhathar Rural Municipality of Dhankuta District
}

\author{
Dinesh Adhikari ${ }^{1}$ \\ Email: dineshadhikari.rd@gmail.com
}

\section{Abstract}

Remittance is an enormous source of income for developing countries as well as Nepal. It contributes largely to the national economy in Nepal and it has also transformed the socio-economic lives of a large number of rural people. Number of remittance receiving household has reached more than 50 percent in the country. The remittances sent home by the migrants affect development of household, community and national levels. At the household level, remittances help to reduce poverty, improve living standard and attain educational needs. remittances could be used for entrepreneurship and productive investment which increases job opportunities and income of the people. Basic needs are fulfilled and released from landless or homeless condition by the use of remittance of rural people. Remittance inflows help to improve the lifestyle of rural people and their account position too. Many of the remittance used to consumption function or unproductive sector in rural area. It is suggested that policies and programs need to be developed for encouraging the utilization of remittances for productive use in order to promote rural growth.

Key words: remittance, basic needs, repayment and lifestyle

\section{Introduction}

Remittance is a transfer of money by a foreign worker to an individual in his or her home country. The government's statistics show that 74 percent Nepali workers employed in foreign labor markets are unskilled. Government grants permissions to work in 109 countries for foreign employment, a majority of workers are leaving for countries like Malaysia, Qatar, United Arab Emirates, Saudi Arabia and Kuwait (DoFE, 2014).

1. Mr. Adhikari is a lecturer of Rural Development at Tribhuvan University, Dhankuta Multiple Campus, Dhankuta. 
According to IMF (2009), remittances means household income from foreign economies arising mainly from the temporary or permanent movement of people to those economies. Remittances include cash and noncash items that flow through formal channels, such as via electronic wire, or through informal channels, such as money or goods carried across borders. They largely consist of funds and noncash times sent or given by individuals who have migrated to a new economy and become residents there, and the net compensation of border, seasonal, or other short-term workers who are employed in an economy in which they are not resident.

World Bank (2019) stated that, Nepali migrant workers sent home $\$ 8.1$ billion in 2018, making it the 19th biggest beneficiary of funds sent by migrants around the world. Five South Asian countries are in the top 20 list of biggest beneficiaries of remittances, with Nepal taking the fourth spot in the region. It is behind India (\$78.6 billion), Pakistan ( $\$ 21$ billion) and Bangladesh ( $\$ 15.5$ billion) but ahead of Sri Lanka ( $\$ 7.5$ billion) in terms of remittances. India is the world's top recipient of remittances followed by China, Mexico, the Philippines and Egypt. The World Bank said that remittances to South Asia grew 12 percent to $\$ 131$ billion in 2018, outpacing the 6 percent growth in 2017.

According to Nepal Rastra Bank statistics, Nepali migrant worker departures plunged 39.2 percent in the first seven months of the 2017/18 fiscal year, compared to a 4.9 percent drop during the same period last year. A sharp decline in the number of people leaving for Malaysia, one of the most popular labour destinations for Nepalese. In a related development, ministers from 12 Asian labour-sending countriesAfghanistan, Bangladesh, Cambodia, China, India, Indonesia, Nepal, Pakistan, the Philippines, Sri Lanka, Thailand, and Vietnam met in Kathmandu on Nov, 2018 in a high-level meeting of the sixth Ministerial Consultation on Overseas Employment and Contractual Labour for Countries of Origin in Asia (Colombo Process) and made a commitment of 'zero-cost' jobs for migrant workers.

Remittances have played an increasingly large role in the economies of small and developing countries. Since the late 1990s, remittances have exceeded development aid, and in some cases make up a significant portion of a country's gross domestic product. According to a report by the World Bank in 2018, $\$ 466$ billion in remittances were sent to low-income and middle-income countries in 2017. If we include high-income countries as well, the total amount of remittances jumps to $\$ 613$ billion. For low-income countries where their economy is struggling to develop, remittances represent one of the largest sources of income for their people. Nepal received remittances worth Rs 699 billion in the Fiscal Year 2016/17 ranking fourth in the list of developing countries with large contribution of remittances to GDP. By 
the fiscal year 2016/17, 4003474 million workers had gone for foreign employment in Nepal. Among them, 38,28,172 males and 1,75,302 were female (Economic Survey 2017/18).

Chhathar Jorpati is one of the rural municipality among the seven local level of dhankuta district._It has an area of 102.83 square kilometers and the total population of the municipality is 18,322 and 1,672 people were out of this municipality as foreign labour. Forming this new Rural Municipality, Hattikharka, Tankhuwa, Telia and Parewadin were merged, which previously were all separated Village development committee (local level administrative villages). The total population \& literacy rate of ward no. 1 (study area) is $3,145 \& 70.6 \%$ respectively within the $12.33 \mathrm{~km}$ square area. Its slope geography is divided into lekh, kachhad and benshi. Majority of the Janajati (Limbu, Magar) People lived in this area, Kshetri, Braman, Dalit, Newar, Sherpa people have dwelled there (CBS,2074 BS). Nobody knew the people's habit of utilization of their income in this area So that, I have focused the study on the uses of their foreign earning in different sectors of consumption.

\section{Methods and Materials}

Study has completed the 50 household's foreign labour migrated of Chhathar Rural Municipality Ward No. 1 Hattikharka of Dhankuta District. Although there is no exact record of foreign labour number in this ward, fifty people of foreign labour and their family are selected by the help of purposive sampling then studied and interviewed with the help of schedule to fulfill the answer of research questions. The question is related to the utilization of remittance in terms of their needs. It is descriptive and analytical in nature of study design. Website, local agency's record and published and unpublished literatures are reviewed and studied for information and getting research gap. The Main objective of the study is to find out the utilization of remittance on their interested field.

\section{Results and Discussion}

The main purpose of abroad entrance is to earn money, to fulfill the family needs and improving the lifestyle of people. Main consumption expenditure of their foreign income is utilization in different necessary area. Migration is an old phenomenon in Nepal. Migrant workers and their families primarily use of remittances for consumption purposes. If this current trend of remittance use continues, the hardly earned money sent by migrants abroad will not be used productively and cannot contribute to economic growth and development of rural people. The main destination of studied area's labour market is Malesia, South Korea, Dubai, Saudi Arabia, Bahrain, Qatar and India too. 
Table 1: Income and Expenditure of Foreign Earning

\begin{tabular}{|l|r|r|r|}
\hline $\begin{array}{c}\text { Annual Income from } \\
\text { Foreign Labour (000) }\end{array}$ & $\begin{array}{c}\text { Number of Foreign } \\
\text { labour }\end{array}$ & $\begin{array}{c}\text { Expenditure } \\
\text { Percentage }\end{array}$ & $\begin{array}{c}\text { Saving } \\
\text { Percentage }\end{array}$ \\
\hline More than Rs.400 & 6 & 56 & 44 \\
\hline Rs.200-400 & 23 & 78 & 22 \\
\hline Below Rs.200 & 21 & 91 & 9 \\
\hline
\end{tabular}

Source: Field Study 2019

The study of fifty foreign labour's earnings, only $12 \%$ of foreign labour have more than 4 lakhs annual income. Many of them are in gulf countries, some of them are in Korea, Malesia. More of the foreign labour (46\%) are on the middle earning group. Forty-two percentage of rural people go to abroad to fulfilment of basic needs of their family in origin country. About fifty percent of income is consumed besides it is saved of higher income group. Middle income group saves only $22 \%$ of their earning and consumed more of their income. Lower income group consumed $91 \%$ of their income due to their poverty and basic needs. They don't change their lifestyle by foreign income because of lower saving and high consumption on basic needs.

Table 2: Main Expenditure Area of Remittance

\begin{tabular}{|l|r|}
\hline \multicolumn{1}{|c|}{ Component of Expenditure } & Percentage of Expenditure \\
\hline Basic Needs & 31 \\
\hline Property Earning (adding) & 46 \\
\hline Investment & 2 \\
\hline Needless expense & 21 \\
\hline
\end{tabular}

Source: Field Study 2019

People expense the different sector of their income differently. people's priority of selection of their needs is not like to all according to their earning. $46 \%$ of the foreign income's spent on property adding or land and residential land purchasing causes of more money expensed of land among the total expenditure. People spent more of their income on basic needs besides property adding. Many of the income also spent on needless matters, luxuries, and daily needs.

\section{Fulfillment of basic needs}

Table 3: Consumption of basic needs to utilization of remittance

\begin{tabular}{|l|r|}
\hline \multicolumn{1}{|c|}{ Basic Needs } & Households Expenditure in \% \\
\hline Food consumption & 48 \\
\hline Clothing & 19 \\
\hline Housing & 7 \\
\hline Education & 23 \\
\hline Health & 3 \\
\hline
\end{tabular}


Many of the abroad employers have earned for basic consumption to daily life of their family who lived in their mother land. People spent their income more in food consumption for survive to daily needs. People have spent their remittance in education, clothing and housing 23,19 and 7 Percentage respectively. Basic needs are basic right of people which is protected in our constitution too. When people didn't earn so much money, their focus is to get housing, food, access of education and health to their children or youngers of family. However, as income increases and they can more easily cover living expenses, the extra cash goes elsewhere. Most of the foreign labours are working in vulnerable situations without any effective legal protection by the Nepalese government or the receiving countries' government.

\section{Investment in household property \& loan payment}

Every rural people who were in abroad have a desire to purchase a house or residential land in town by the foreign earning. Many of the foreign income spend on land purchasing and loan repayment. Above 70 percent foreign employer have got loan for going abroad and only a few foreign labour migrant spent own their property. All of the borrower have payed their loan, no one is remains to pay . Many higher income group's labour and low middle income group's labour could buy the land property but lower income group's are on the subsistence economic level so they could not afford any things without basic needs. $23 \%$ foreign labour have brought land for living purpose. Some of the worker's family used the remittance to buy gold and silver for ornament. Furniture and Kichan goods are added with the help of remittance in city among the all foreign migrants.

\section{Investment}

There are two types of advantage by worker's and remittance. Knowledge, experience and skilled of returned worker from abroad are useful to trade, entrepreneurism, horticulture, business and agricultural activities. The study shows that remittance is playing increasingly important role for economic growth. Only a few workers invested lending their money to other and some of them keeping animals, horticulture, apiculture, poultry. Due to the small investment of cottage industry and modern agriculture, poverty and unemployment are going to reduced and subsistence level of lives converted into livelihood and commercial lives.

Near about 25 Percent foreign labour who had already gone for earning not revised to do again according to their view and engaged to small business, animal husbandry, poultry form, bees keeping, vegetable farming commercially. They returned home with strong experience and knowledge and hardworking to profession. Every returned labours from foreign employment engaged and busy in any tasks. As a comparison of returned foreign labour and local level people to do professional skills, knowledge and courage, they are more batter than local people. The positive impacts 
of the remittance are the improvement in literacy and educational status, changes in the beliefs of people, change in social status of people, emigrated people seem to be more aware politically, the desire to participate in festival and religious ceremonies has increased.

\section{Needless consumption}

All income from the abroad is not spent properly and rationally always. Purchasing luxuries good like electronic goods, higher value equipment and vehicles spent more money. emigrant's families are influenced by demonstration effects, that is, the money obtained from remittance are being invested in unnecessary or unproductive areas. Addict of alcoholism and suffered from venereal diseases, possibility of not returned back of family member, family break up and death of family member in country of destination are noted as other negative social impacts and the area of undesired expenditure. Level of consumption of people have increased by the flow of remittance. Not doing work when finished the expense and playing gambling are some of the challenging task to control and utilization of remittance.

\section{Saving}

The study found out that remittance inflow has a positive effect on financial inclusion by promoting the use of deposit accounts and they do not get to borrow again for basic purpose of household. Saving of remittance in bank is most important for security and using in scarcity of needed things. All of the family of foreign labour opened account in bank. A labour work in abroad and their all family depended on this remittance seemed not more saving their earning. Above the $90 \%$ of saving has used in daily life consumption.

\section{Conclusion}

Remittances are often used as a way to help raise the standard of living and fulfilment of basic needs and help to combat rural poverty. In fact, since the late 1990s, remittances have exceeded development aid, and make up a significant portion of a country's gross domestic product. A significant number of Nepalese people are now receiving remittance earnings to finance their expenditures in home consumption, health and in children's education. Many of the remittance received from abroad expensed in consumption function. A labour has worked in abroad and all of his/her family depend up on him/her. It supports the human capital building and availability of financial resources. A critical challenge facing Nepal with huge remittance receipts is to mobilization and sustainable utilization of saving for productive purpose.

\section{References}

CBS (2074 BS). Gaunpalika/Nagarpalika Tathyankiya Ruprekha. Dhankuta: Authors CBS(2010/11). Nepal living standard survey III. Kathmandu: Authors 
DOFE (2014). Labour migration for employment: status report for Nepal: 2013/2014. Kathmandu: Authors

IMF (2006). Selected issues and statistical appendix Nepal. IMF Country Report No. 06/45. February.

MOF (2018). Economic survey 2017/2018. Ministery of Finance Nepal Nepal Rastra Bank (2076 BS). Nepal ma Bipresan Prabahko Sthiti. Kathmandu: NRB. World Bank (2019). Migration and remittance. Washington: World Bank. 